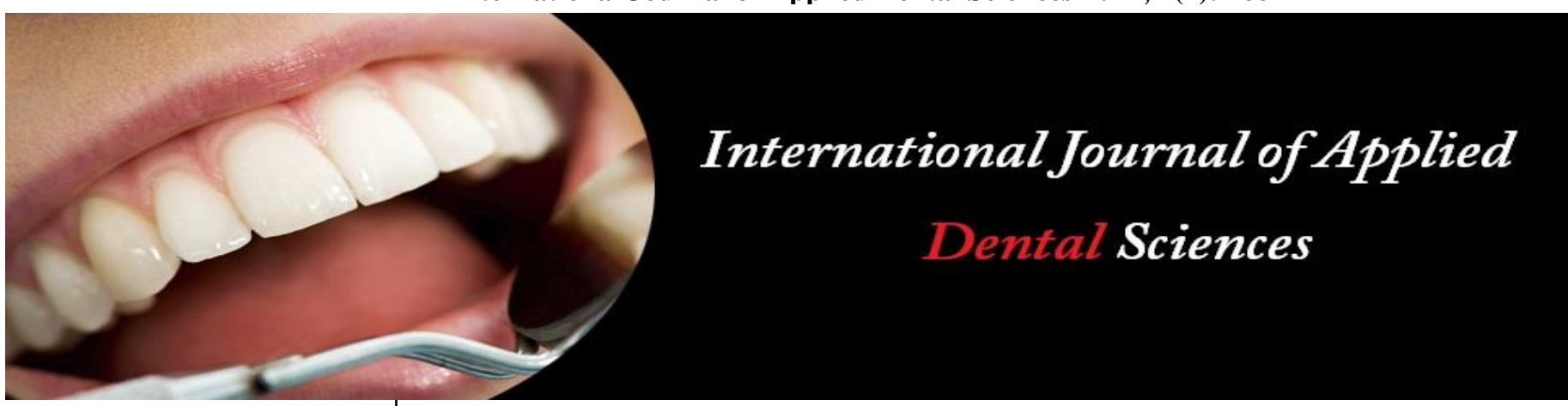

ISSN Print: 2394-7489

ISSN Online: 2394-7497

IJADS 2021; 7(1): 268-271

(C) 2021 IJADS

www.oraljournal.com

Received: 15-11-2020

Accepted: 18-12-2020

Dr. Bushra ul Anne Syed Oral and maxillofacial

department, Abbassi shaheed hospital, Karachi, Sindh,

Pakistan

Dr. Anita Jumani

Dental surgeon, Baqai medical university, Karachi, Dept. Oral medicine department,

Sindh, Pakistan

Dr. Nazish Ashfaq Khan Consultant, Department of Oral and maxillofacial Surgery, Abbassi shaheed hospital, Karachi, Sindh, Pakistan

Dr. Amina Usmani

Oral and maxillofacial

department, Abbassi shaheed

hospital, Karachi, Sindh,

Pakistan

Dr. Sabar Sardar

Oral and maxillofacial

department, Abbassi shaheed

hospital, Karachi, Sindh,

Pakistan
Corresponding Author: Dr. Nazish Ashfaq Khan Consultant, Department of Oral and maxillofacial Surgery, Abbassi shaheed hospital, Karachi, Sindh, Pakistan

\section{Perceptions and practices of water pipe (Sheesha) smoking among medical, dental and pharmacy students}

\author{
Dr. Bushra ul Anne Syed, Dr. Anita Jumani, Dr. Nazish Ashfaq Khan, Dr. \\ Amina Usmani and Dr. Sabar Sardar
}

DOI: $\underline{\text { https://doi.org/10.22271/oral.2021.v7.i1d.1143 }}$

\section{Abstract}

Objective: To determine the perception and practices of waterpipe (sheesha) smoking among Medical, Dental and pharmacy students.

Introduction: Waterpipe (Sheesha) smoking is on the rise among the youth, all over the world. Various Cafes and restaurants have been established which serve waterpipe (sheesha). Although common among all age groups it is particularly popular among teenagers who are oblivious to the health problems and dangers associated with waterpipe (sheesha) smoking.

Study Design: Cross sectional study.

Place and duration: This study was conducted in Baqai medical university and Dow University of health sciences from 1st June 2013 to 31 st March 2014.

Materials and Methods: A total of 300 students of all classes were selected by

systematic random sampling technique (every 3rd student was taken). Unwilling and non-cooperative students were excluded. All the students were subjected to fill a pre-design and prepared questionnaire designed to find out the perceptions and practices of students regarding waterpipe (sheesha) smoking.

Results: The study showed that $138(46 \%)$ of the students exactly involved in the practice of waterpipe (sheesha) smoking. 53(38\%) D-pharm student while 48(35\%) MBBS student and 37(27\%) BDS students are involved in this practice.85 $(28.3 \%)$ of the students used to smoke waterpipe (sheesha) in a café. 263 (87.7\%) out of 300 students knew about the hazards of waterpipe (sheesha) smoking.

Conclusion: D-pharmacy students are mostly involved while MBBS are less involved and BDS are least involved. Most students knew about waterpipe (sheesha) and its hazards, more than half of them were involved in waterpipe (sheesha) smoking. Most of the students started smoking waterpipe (sheesha) because their friends smoked.

Keywords: waterpipe (sheesha), medical, dental and pharmacy students

\section{Introduction}

Tobacco usage is the leading avertable root cause of global fatality, and according to the most recent estimates, more than $80 \%$ of the 8.3 million tobacco-attributable deaths in 2030 will occur in undeveloped countries ${ }^{[1]}$. Smoking in any form can be fatal. Health hazard includes cardiovascular diseases, lung cancer, chronic bronchitis, and respiratory diseases ${ }^{[2,3]}$. These appalling predictions emphasize the necessity for developing nations to scrutinize patterns and determinants of tobacco usage, recognize local tobacco use methods, build up efficient cessation interventions, and guide their own tobacco control volunteers ${ }^{[4]}$.

Health professionals are expected to play an important task in smoking impediment and control. The WHO (World Health Organization), encourages health professionals to give their patients information about the health hazards of smoking, help their patients quit smoking and encourage a tobacco free standard of living ${ }^{[5]}$.

There is evidence to suggest that even a three minute advice on smoking cessation delivered effectively by a health professional can result in $2 \%$ of smokers quitting this habit (6). It's been seen that Waterpipe (sheesha) has been used by the native African and Asians for smoking tobacco for virtually 400 years ${ }^{[7]}$. It has been concluded that $>100$ million people globally smoke water pipes (sheesha) on a daily basis ${ }^{[7,8]}$. 
Water pipes (sheesha) entail the channel of smoke through water preceding to gasp. Although used to smoke other substances, counting marijuana and hashish, water pipes (sheesha) are most frequently used to smoke flavored tobacco, which is prepared by the amalgamation of shredded tobacco with honey or molasses and fruit in dried form. Current studies do not sustain these perceptions. Although research is partial, the offered substantiation suggests that water pipe (sheesha) smoking related health risks are akin to those of cigarette smoking. The up to date meta-analysis revealed that water pipe (sheesha) tobacco smoking was drastically allied with lung cancer, respiratory disorders, low birth weight and periodontal problems ${ }^{[9,10]}$. Literature shows that in Pakistan, the information concerning waterpipe (sheesha) smoking is quite scanty. Very few studies have been conducted to determine common smoking patterns and the prevalence of smoking practice among medical students.

\section{The objectives of the present study were}

1. To determine the prevalence of waterpipe (sheesha) smoking among medical, dental and pharmacy students in different colleges of Karachi.

2. To discover their attitudes and practices about waterpipe (sheesha) smoking routine.

3. To make a comparison amongst students of different universities of Karachi regarding their waterpipe (sheesha) smoking practice.

4. To appraise their awareness about the hazards of waterpipe (sheesha) smoking.

5. To wrap up, which medical field is to a great extent drawn in this practice of waterpipe (sheesha) smoking?

\section{Materials and Methods}

A Cross sectional descriptive study was conducted at Baqai Medical University and Dow University of Health Sciences, Karachi. The extent of the study was 10 months from June $1^{\text {st }}$ 2013 to March $31^{\text {st }} 2014$. The study populace comprised of existing students from $1^{\text {st }}$ year to final year of M.B.B.S, B.D.S and D. Pharm. The study integrated a total number of 2 universities, both have dental, medical and pharmacy colleges. These colleges were having a total number of 2500 enrolled first to fifth year students, 750 medical, 750 dental and 1000 Pharmacy students. The questionnaire had a total number of 10 items.

The participants were selected by systemic haphazard sampling with every third student of each class being integrated in the mock-up. The subjects were included irrespective of gender and age.

The data compilation tool, implied was a prepared and predesigned questionnaire. Different questions, concerning knowledge about waterpipe (sheesha), whether the individual smoked waterpipe (sheesha) and duration of smoking waterpipe (sheesha) were asked. Collected data was analyzed with the aid of SPSS - 16 for calculations of frequencies and percentages.

\section{Results}

A total number of 300 students were included in the study. It was noted that $138(46.0 \%)$ of the surveyed sample indicated they were waterpipe (sheesha) smokers while 162(54.0\%) students did not smoke. 153(51.0\%) male students and $147(49.0 \%)$ female students smoked waterpipe (sheesha). There were $108(36.0 \%)$ students who had been smoking waterpipe (sheesha) for more than a year while $46(15.3 \%)$ medical students had been smoking for less than one year.
Majority of the students did not smoke waterpipe (sheesha)'daily' or weekly. Among the waterpipe (sheesha) smoking students, 104(34.7\%) students used to smoke waterpipe (sheesha) occasionally, 33(11\%) students were in the habit of smoking waterpipe (sheesha)weekly and 18(6\%) students indicated that they smoked waterpipe (sheesha) daily. $85(28.3 \%)$ respondents used to visit café for waterpipe (sheesha) smoking, 63(21\%) preferred open air for waterpipe (sheesha) smoking, 13(4.3\%) students cited their homes as the place of smoking.

Table 1: Duration, Frequency \& Place of waterpipe (sheesha) smoking.

\begin{tabular}{|c|c|c|}
\hline Variable & Students & Percent \\
\hline Duration of waterpipe smoking & & \\
\hline More than a year & 46 & $15.3 \%$ \\
\hline Less than a year & 108 & $36 \%$ \\
\hline Frequency of waterpipe smoking & & \\
\hline Weekly & 33 & $11 \%$ \\
\hline Daily & 18 & $6 \%$ \\
\hline Occasionally & 104 & $34.7 \%$ \\
\hline Place of waterpipe smoking & & \\
\hline Café & 13 & $4.3 \%$ \\
\hline Open air & 63 & $21 \%$ \\
\hline Home & 85 & $28.3 \%$ \\
\hline
\end{tabular}

Figure 1 exhibits the reasons of waterpipe (sheesha) smoking in the participants. The prime motive for waterpipe (sheesha) smoking mentioned by the participants was outing with friends and their company. $113(37.7 \%)$ students started smoking waterpipe (sheesha) because their friends were indulging in the same, 17(5.7\%) medical students revealed that family members were the main motive, 29(9.7\%) students started this habit smoking waterpipe (sheesha) out of (curiosity and social obligation) others.

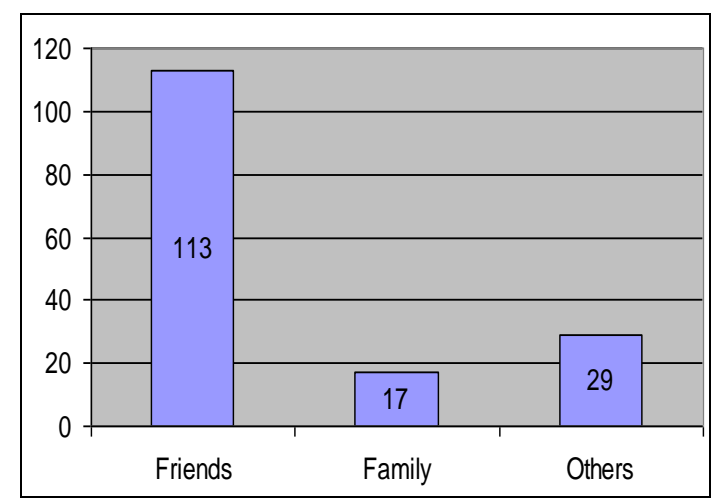

Fig 1: Exhibits the reasons of waterpipe (sheesha) smoking in the participants.

Table 2 shows 263(87.7\%) out of 300 respondents knew about the hazards of waterpipe (sheesha) smoking and $35(11.7 \%)$ did not know about the hazards.

$82(27.3 \%)$ students used disposable tips while $80(26.7 \%)$ did sessions without a disposable tip. 57(19\%) students wanted to quit this habit while 101(33.7\%) did not want to quit it.

Table 2: Awareness about Hazards of Water Pipe Smoking

\begin{tabular}{|c|c|c|}
\hline Variable & Yes n(\%) & No n(\%) \\
\hline Hazards of waterpipe smoking & $263(87.7 \%)$ & $35(11.7 \%)$ \\
\hline Disposable tips for waterpipe smoking & $82(27.3 \%)$ & $80(26.7 \%)$ \\
\hline Quit from waterpipe smoking & $57(19 \%)$ & $101(33.7 \%)$ \\
\hline
\end{tabular}


The faculty which is mostly involved in the practice of waterpipe (sheesha) smoking is D-pharm which is $53(38 \%)$ while MBBS is $48(35 \%)$ and least is BDS i.e $37(27 \%)$

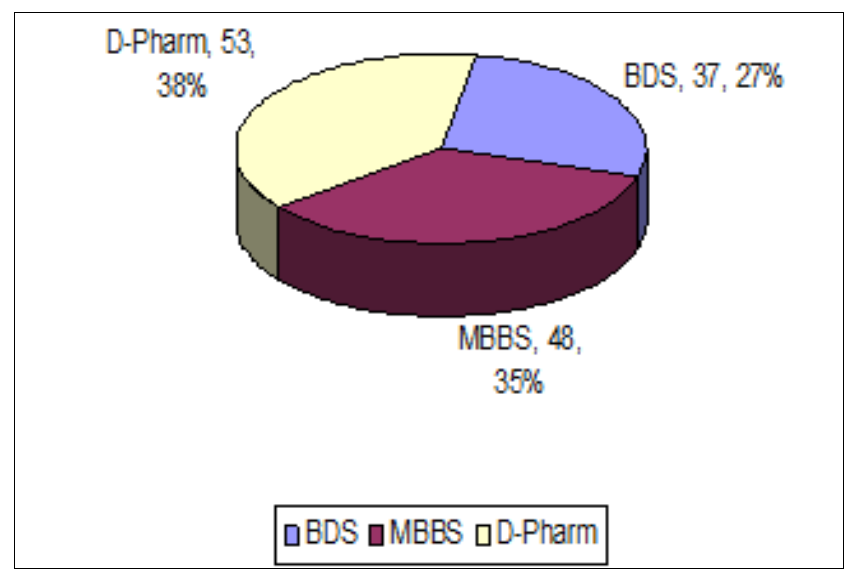

Fig 2: Faculty which is mostly involved

\section{Discussion}

An analysis of mainstream water pipe smoke (i.e., inhaled by the user) found large amounts of carcinogens, hydrocarbons, and heavy metals, including 36 times the amount of tar as in cigarette smoke. Water pipe tobacco smoking often occurs in a social setting, among friends at a private residence, or in venues that offer ready to smoke water pipes to customers ${ }^{[11,}$ 12]

In this study $300(66.66 \%)$ students out of 450 responded. In which $250(55.55 \%)$ of the study conducted in BAQAI Medical University and 200(44.44\%) of the study conducted in Dow University of Health Sciences.

In our study $138(46 \%)$ students smoke waterpipe (sheesha) smoking while $162(54 \%)$ did not smoke waterpipe (sheesha) in which male are $153(51 \%)$ and female are $147(49 \%)$. The age group involved if from 17years to 26years in which 20year of students are mostly involved i.e 58(19.3\%).

In our study majority $85(28.4 \%)$ of respondents prefer to smoke in a café while 63(21\%) used to smoke in open air and only $13(4.3 \%)$ used to smoke at home.

This study reported that a large chunk 113(37.7\%) of respondents started smoking waterpipe (sheesha) because their friends smoked waterpipe (sheesha). It depicts that majority of waterpipe (sheesha) smokers are influenced by their friends company. Study and discussion has reported that only $17(5.7 \%)$ of participant started waterpipe (sheesha) smoking because their family member also smokes waterpipe (sheesha). 29(9.7\%) students started this habit smoking waterpipe (sheesha) out of curiosity and social obligation.

The awareness regarding hazardous effect of waterpipe (sheesha) smoking shows that 263(87.7\%) of those participants were aware of waterpipe (sheesha) smoking while $35(11.7 \%)$ students did not aware with its hazards.

About 65(21.7) student's family are familiar with this habit while $108(36 \%)$ wont familiar with this habit.

Majority of the students did not smoke waterpipe (sheesha)'daily' or weekly. Among the waterpipe (sheesha) smoking students, 104(34.7\%) students used to smoke waterpipe (sheesha) occasionally, 33(11\%) students were in the habit of smoking waterpipe (sheesha) weekly and $18(6 \%)$ students indicated that they smoke waterpipe (sheesha) daily. The $71(23.7 \%)$ respondents believes that they feel relaxed after having session of smoking while 54(18\%) feel freshed and $28(9.3 \%)$ feel satisfied. There were 108(36.0\%) students who had been smoking waterpipe (sheesha) for more than a year while $46(15.3 \%)$ medical students had been smoking for less than one year.

$82(27.3 \%)$ students used disposable tips while 80(26.7\%) did sessions without a disposable tip. 57(19\%) students wanted to quit this habit while 101(33.7\%) did not want to quit it.

The increasing trend of water pipe smoking can be attributed to several is conceptions. These include the popular beliefs that the nicotine content in water pipes is lesser as compared to cigarettes and that the water used in this form of tobacco intake filters out all the hazardous chemicals such as carbon monoxide, nicotine and tar ${ }^{[13]}$. These common misconceptions escort the public to believe that water pipe smoking is not a significant health hazard ${ }^{[14]}$.

In Pakistan, the information regarding waterpipe (sheesha) smoking is scarce and that is a hindrance in effective intervention. Only few studies were conducted to determine wide-ranging smoking pattern to the selected areas and specific population groups ${ }^{[14,15,16]}$ Furthermore, few studies are conducted in Pakistan for prevalence of smoking habits among medical students.

\section{Conclusion}

According to our research waterpipe (sheesha) smoking is very well-liked among medical students in which D-pharmacy student are mostly drawn in than MBBS and BDS. Most of the students know about hazards of waterpipe (sheesha) smoking and they usually prefer waterpipe (sheesha) café for waterpipe (sheesha) smoking. An attention-grabbing fact is that mostly students start waterpipe (sheesha) smoking because of their friends. Steps should be taken to engross students in healthy recreational activities.

Tobacco control programmes should be conducted in colleges and awareness among people should be created through electronic and print media. Our study reveals the alarming situation of waterpipe (sheesha) smoking among medical students and thus active actions should be taken to control this current trend especially among students by raising awareness about the hazards of waterpipe (sheesha) smoking.

\section{References}

1. Mathers CD, Loncar D. Projection of global mortality and burden of disease from 2002 to 2030. PLoS Med. 2006;3(11):e442. [PMC free article] [PubMed]

2. Khan N, Siddique MU, Padhiar AA, Hashmi SAH, Fatima S, Muzaffar S. Prevalence, knowledge, and practice of shisha smoking among medical and dental students of Karachi, Pakistan. JDUHS 2008;2(1):3-10

3. Marsh DR, Kadir MM, Hussein K et al. Adult mortality in slums of Karachi, Pakistan. J Pak Med Assoc 2000;50:300-6

4. Maziak W, Arora M, Reddy KS, Mao Z. On the gains of seeding tobacco research in developing countries. Tob Control 2006;15(1):i3-i4. [PMC free article] [PubMed]

5. The GTTS Collaborative Group.Tobacco use and cessation counseling: Global Health

6. Professionals Survey Pilot Study, 10countries, 2005. Tobacco Control 2006;15(II):ii31-ii34

7. Watt R, Robinson M. helping smokers to stop: A guide for the dental team; Health Education Authority: London 1999.

8. Koul PA, Hajni MR, Sheikh MA, Khan UH, Shah A, Khan Y et al. Hookah Smoking and Lung Cancer in the Kashmir Valley of the Indian Subcontinent. Asian Pacific Journal of Cancer Prevention 2011;12:519-24

9. Wolfram RM, Chehne F, Oguogho A et al. fcooj/ 
Narghile (water pipe) smoking influences platelet function and (iso) eicosanoids. Life Sci 2005;74:47-53

10. Maziak W. The waterpipe: time for action. Addiction 2008;103:1763-7.

11. Akl EA, Gaddam S, Gunukula SK, Honeine R, Jaoude PA. The effects of waterpipe tobacco smoking on health outcomes: a systematic review. Int. J Epidemiol 2010;39:834-57.

12. Tamim R, fero A, Kassem H. Tobacco use by university students, Lebanon. Addiction 2003;98:933-9.

13. Maziak W, KSstam S, Eissenberg T. Render and smoking status-based analysis of views regarding water pipe and smoking in Aleppo, Syria. Prev Med 2004;38:479-84.

14. Rehman S, Sadiq MA, Parekh MA, Zubariri ABS, Frossard PM, Khan JH. Cross-sectional study identifying forms of tobacco used by Shisha smokers in Pakistan $\mathbf{J}$ Pak Med Assoc 2012;62(2):192-95

15. Shihadeh A, Azar S, Antonios C, Haddad A. Towards a topographical model of narghile water pipe café smoking: a pilot study in high socioepofiomic status neighborhood of Beirut, Lebanon. Pharmacol Biochem 